Gabor KEMENY

University of Public Service, Hungary

Hungarian National Police

research@kemeny.cloud

ORCID 0000-0003-0062-2160

https://doi.org/10.34739/dsd.2020.02.02

\title{
EFFICIENCY OF CROSS-BORDER INFORMATION EXCHANGE
}

\begin{abstract}
The aim of this paper is to provide an insight into the influencing factors of international police information exchange conducted by the Single Points of Contact (SPOC) and the Police and Customs Cooperation Centre (PCCC) within the EU. The author achieves this goal by introducing the relevant scientific theories and the results of the conducted quantitative research. The research identifies the influencing environments of cross-border information exchange and through this, finds supporting and hindering factors such as organisational structure, culture, leadership, legislation, and ICT environment. Findings can help decision makers and end users to overcome everyday obstacles.
\end{abstract}

KEYWORDS: law enforcement cooperation, information exchange, European Union, Schengen, transborder crime, EU law

\section{EFEKTYWNOŚĆ TRANSGRANICZNEJ WYMIANY INFORMACJI}

ABSTRAKT: Celem niniejszego artykułu jest przedstawienie czynników wpływających na międzynarodową wymianę informacji policyjnych prowadzoną przez unijne Pojedyncze Punkty Kontaktowe (SPOC) oraz Centrum Współpracy Policyjno-Celnej (PCCC). Autor stara się osiągnąć ten cel przedstawiając wybrane teorie naukowe i wyniki przeprowadzonych badań ilościowych. Artykuł identyfikuje środowisko transgranicznej wymiany informacji, a dzięki temu wskazuje czynniki wspierające i utrudniające, takie jak struktura organizacyjna, kultura, przywództwo, prawodawstwo i środowisko ICT. Wyniki badań mogą pomóc decydentom i użytkownikom pokonywać codzienne przeszkody w tej dziedzinie.

SŁOWA KLUCZOWE: współpraca organów ścigania, wymiana informacji, Unia Europejska, Schengen, przestępczość transgraniczna, prawo UE

\section{INTRODUCTION}

International police cooperation became important with the signature of the Schengen Convention in $1985^{1}$. To safeguard internal security and to ensure the elimination of the security deficit caused by the abolition of checks at the internal borders, police cooperation became

\footnotetext{
${ }^{1}$ European Union, The Schengen Acquis - Convention Implementing the Schengen Agreement of 14 June 1985 between the Governments of the States of the Benelux Economic Union, the Federal Republic of Germany and the French Republic on the Gradual Abolition of Checks at Their C, Brussels, 1985.
} 
a complementary measure ${ }^{2}$. The convention lists the modes of cooperation, with Article 39 encouraging the police authorities of the Member States (MS) to assist each other in preventing and detecting criminal offences. Single Points of Contact (SPOC) and the Police and Customs Cooperation Centre (PCCC) information exchange is conducted under this convention. The SPOC was created to facilitate all types of information exchange by "putting one police service in every state in charge of international cooperation, a single contact point strategy, therefore centralizing the process of police cooperation"3. The creation of the PCCC was the answer to the emerging need for a less centralised and direct channel among neighbouring countries to help operational activities in the border areas ${ }^{4}$. Since 2005, the importance of these channels significantly increased as a result of the EU enlargement and because of the different security threats that arise and which show a cross-border character ${ }^{5}$. Although the importance of cross-border information exchange was recognised by various agencies and institutions in the $\mathrm{EU}^{6}$, yet personal experiences show that there are serious shortcomings in cross-border information exchange when rapid and efficient information is required to properly fulfil the police tasks ${ }^{7}$.

The aim of the research is to determine those factors, which are hindering and supporting the efficiency of the information exchange conducted by the above-mentioned channels, hence, to provide assistance to the decision makers and practitioners to develop an efficient information exchange system.

\section{THEORETICAL REVIEW}

\section{DEFINITION AND LEVELS OF INFORMATION EXCHANGE}

Information exchange is a type of cross-border police cooperation, it can be defined as the formal and informal sharing of significant and timely information between two or more parties ${ }^{8}$. We can conclude from the academic literature that information exchange can be conducted on three interrelated levels: interpersonal, intra-organisational, and inter-organisational ${ }^{9}$. Even though there is a strong distinction between these levels, it is clear that they are interrelated and should be

\footnotetext{
${ }^{2}$ European Commission, Enhancing Police and Customs Cooperation in the European Union [COM (2004) 376 Final - Not Published in the Official Journal], 2004, p.9.

${ }^{3}$ D. Weibel, Police and Border Cooperation in Schengen: The Police and Customs Cooperation Center (PCCC). Leiden 2016, p. 2.

${ }^{4}$ M. Saloven et al., Study on the Status of Information Exchange amongst Law Enforcement Authorities in the Context of Existing EU Instruments, Brussels 2010, p.70.

${ }^{5}$ European Commission, A European Agenda on Migration COM(2015) 240 Final, 2015.

${ }^{6}$ Frontex, Roles \& Responsibilities, European Police Office, Serious and Organised Crime Threat Assessment, 2017.

${ }^{7}$ G. Kemeny, A qualitative analysis of the hindering and supporting factors of the cross-border information exchange conducted by the single point of contact and the police and customs cooperation centre, „Public Security and Public Order" 2020 (24), p.102.

${ }^{8}$ B. Cater, The Importance of Social Bonds for Communication and Trust in Marketing Relationships in Professional Services, Management 2008 (13), p. 3.

${ }^{9}$ Vide A. Mausolf, Keeping Up Appearances: Collaboration and Coordination in the Fight against Organized Crime and Terrorism, Leiden 2010.
} 
connected to each other to create an efficient information-sharing environment ${ }^{10}$. This theory is supported by other researchers. M. Saloven and others argue that weak internal coordination and intra-organisational information exchange can negatively influence cross-border information exchanges ${ }^{11}$.

Besides the (inter)connection of the levels, efficient information sharing requires adequate organisational-managerial, legal, and technological environments ${ }^{12}$, which are determined by various factors such as the Information and Communication Technology (ICT), organisational structure, culture and values, human resources, trust, leadership, rewards, self-interest, legal instruments and regulations ${ }^{13}$.

\section{Centralisation}

In the literature, two main types of organisational structure are distinguished: bureaucracy and adhocracy ${ }^{14}$. Bureaucracy can be characterized by a formalized and hierarchized structure and by standardized regulations and procedures ${ }^{15}$. H.G. Rainey describes formalisation as "the extent to which an organisation's structures and procedures are formally established in written rules and regulations" ${ }^{16}$. Strong centralisation and formalisation hinder initiatives and actions for the exchange of information, as the exchange is strictly controlled by the managerial authority ${ }^{17}$.

\section{INNOVATION AND STAFFING (ORGANISATIONAL SUPPORT)}

Conducted literature review proofs that the previously described formalisation has a negative impact on innovation and openness to new ideas ${ }^{18}$. Researchers also argue that the conditions of human resources also influence the exchange of cross-border information. T.M. Yang and T.A. Maxwell state that the lack of staff can hamper cross-border information exchange, as the agency "may focus on urgent issues within its own organisation when the immediate benefits of sharing information cannot be foreseen"19. This theory is supported by other research, which states

\footnotetext{
${ }^{10}$ T.M. Yang, T.A. Maxwell, Information-Sharing in Public Organizations: A Literature Review of Interpersonal, IntraOrganizational and Inter-Organizational Success Factors, "Government Information Quarterly 2011 (28), p. $164,171$.

${ }^{11}$ M. Saloven et al., op. cit., p. 83.

${ }^{12}$ T.M.Yang, T.A. Maxwell, op. cit., p. 161.

13 J. Zhang, S.S. Dawes, Expectations and Perceptions of Benefits, Barriers, and Success in Public Sector Knowledge Networks, "Journal of Enterprise Information Management" 2006 (18), p.433.

${ }^{14}$ Vide H. Mintzberg, The Structuring of Organizations, London 1989.

${ }^{15}$ L. Argote et al., Knowledge Transfer in Organizations: Learning from the Experience of Others, "Organizational Behavior and Human Decision Processes" 2000 (82), p.82.

${ }^{16}$ H.G. Rainey, Understanding and Managing Public Organizations, San Francisco 1992, p. 209.

${ }^{17}$ M.J. Wheatley, Leadership and the New Science: Discovering Order in a Chaotic World, San Francisco 2006;

S. Kim, H. Lee, The Impact of Organizational Context and Information Technology on Employee KnowledgeSharing Capabilities, "Public Administration Review" 2006 (66), p.66.

18 D.M. Rousseau, Characteristics of Departments, Positions, and Individuals: Contexts for Attitudes and Behavior, "Administrative Science Quarterly" 1978 (23), p.23; J. Arches, Social Structure, Burnout, and Job Satisfaction, "Social Work" 1991 (36), p.36.

19 T.M. Yang, T.A, Maxwell, op. cit., p. 170.
} 
that one of the main reasons for delays in response is the increase in information exchange, which is not followed by an increase in staff ${ }^{20}$.

\section{ORGANiSATIONAL CULTURE}

Besides the structure, organisational values and culture also influence the attitudes of individuals and the collective actions regarding information sharing ${ }^{21}$. Organisational differences, such as diverse national systems, different culture, division of police tasks among various organisations create misunderstandings and can hamper cross-border police cooperation ${ }^{22}$. However, inter-organisational information exchange are positively influenced by an organisational culture that emphasizes fairness, mutual interests, and shared goals and which decreases the internal competition $^{23}$.

\section{LEADERSHIP}

Researchers found that "the style of the leadership can enforce the negative and positive attitude towards information exchange" 24 . An authoritarian leadership style, for example, can dissuade staff from developing a positive approach towards information sharing. Contrary to this, transformational leadership encourages and supports staff to initiate and exchange information by providing vision and guidance ${ }^{25}$.

\section{INCENTIVES AND REWARDS}

Next important factor we shall mention is linked to the rewards and incentives. A performance-based reward system designed specifically to encourage information exchange motivates individuals to share information and thereby greatly facilitates information exchange ${ }^{26}$. On the other hand, nonspecific incentive methods can hinder inter-organisational information exchange as it creates competition among the staff ${ }^{27}$.

\footnotetext{
${ }^{20}$ R. Doherty et al., Study on the Implementation of the European Information Exchange Model (EIXM) for Strengthening Law Enforcement Cooperation, European Commission, Brussels 2015, p. 29.

${ }^{21}$ D. Constant et al., What's Mine Is Ours, or Is It? A Study of Attitudes about Information Sharing, "Information Systems Research" 1994 (5), p.400.

${ }^{22}$ I. Styczyńska, E.Z. Beaumont, Easing Legal and Administrative Obstacles in EU Border Regions, Brussels 2017, p. 9.

${ }^{23}$ G.W. Bock et al., Behavioral Intention Formation in Knowledge Sharing: Examining the Roles of Extrinsic Motivators, Social-Psychological Factors, and Organizational Climate, "MIS Quarterly" 2005 (29), p. 87.

${ }^{24}$ D. Resteigne, S. Van den Bogaert, Information Sharing in Contemporary Operations: The Strength of SOF Ties, Cham 2017, p. 58.

${ }^{25}$ J. Soeters, Information Sharing in Military and Security Operations, Cham 2017; T.M. Yang, T.A. Maxwell, op. cit., p. 173.

${ }^{26}$ A. Willem, M. Buelens, Knowledge Sharing in Public Sector Organizations: The Effect of Organizational Characteristics on Interdepartmental Knowledge Sharing, "Journal of Public Administration Research and Theory" 2007 (17), p. 581.

${ }^{27}$ J. Zhang et al., Exploring Stakeholders" Expectations of the Benefits and Barriers of E-government Knowledge Sharing, "Journal of Enterprise Information Management" 2005 (18), pp. 548, 552.
} 


\section{PERSONAL RELATIONSHIP AND ITS INFLUENCE}

Trust is a crucial relationship building block which significantly influences interorganisational cooperation and information exchange. J. Zhang and others state that a positive relationship between the degree of trust and the will for information sharing seems to exist ${ }^{28}$. This positive correlation can be experienced in the field of international police cooperation where mutual trust and personal relationships are the most compelling forces ${ }^{29}$. This trust can be developed and maintained by timely, reliable, and adequate information sharing and is influenced by the extent of competence, benevolence, and integrity of the organisation ${ }^{30}$.

The scientific literature shows that, in addition to trust, reciprocity promotes and stabilizes international cooperation and positively influences the individual"s attitude towards information sharing as $^{31}$. A positive correlation exists between the extent of information sharing and the degree of reciprocal interdependence, meaning that each participating organisation possesses information that others need and vice versa ${ }^{32}$. Research on cross-border information exchange also argues that reciprocity and delayed responses are correlated ${ }^{33}$. Another important supporting factor, which is correlated with reciprocity, is reputation, which is significant to facilitate trust building. The lack of reciprocal action results in a loss of reputation ${ }^{34}$.

\section{LEGISLATIVE ENVIRONMENT}

The ruling policies and the legal environment have an impact on the behaviour of individuals and organisations, and thus on the cooperation between the organisations. Stable and accountable legislation and administrative procedures - who has access to what information and how- can mitigate the risks and can enhance inter-organisational cooperation ${ }^{35}$. Researchers argue that confidentiality and privacy should be supported by the legal environment to facilitate information exchange $^{36}$. Clear legislation, regulation, and policies are therefore fundamental to reduce uncertainties created by a difference in organisational culture ${ }^{37}$. On the other hand, not harmonised national legislations and interpretation of the EU instruments, furthermore, a rigid legal environment and policies that prohibit sharing can hamper cooperation and information exchange ${ }^{38}$.

\footnotetext{
${ }^{28}$ J. Soeters, op. cit., p. 85.

${ }^{29}$ S. Hufnagel, Policing Cooperation across Borders, London 2016, p. 86.

${ }^{30}$ L. Bstieler, Trust Formation in Collaborative New Product Development, "Journal of Product Innovation Management" 2006 (23), p. 56.; J. Sydow, Trust within and between Organizations, Oxford 1998.

${ }^{31}$ R. Axelrod, W.D. Hamilton, The Evolution of Cooperation, "Science New Series" 1981 (211), p.1390.;

D. Constant et al., op. cit., pp. 400-421; G.W. Bock et al., op. cit.

${ }^{32}$ B. Travica, Information Aspects of New Organizational Designs: Exploring the Non-Traditional Organization,

"Journal of the American Society for Information Science" 1998 (49), pp. 1224, 1228.

${ }^{33}$ R. Doherty, et al., op. cit., p. 29.

34 S.T. Koeszegi, Trust-building Strategies in Inter-organizational Negotiations, "Journal of Managerial Psychology" 2004 (19), p.640.

35 J. Zhang, S.S. Dawes, op. cit.; C. Lane, R. Bachmann, The Social Constitution of Trust: Supplier Relations in Britain and Germany, "Organization Studies" 1996 (17), p. 365.

${ }^{36}$ J.R. Gil-García et al., E-Government Success Factors: Mapping Practical Tools to Theoretical Foundations, "Government Information Quarterly" 2005 (22), p.187.

${ }^{37}$ J. Zhang, S.S. Dawes, J. Sarkis, op. cit.

${ }^{38}$ J.R. Gil-García et al., op. cit.; I. Styczyńska, E.Z. Beaumont, op. cit.
} 


\section{TECHNOLOGICAL ENVIRONMENT}

Efficiency of inter-organisational collaboration and information exchange can be increased by the advancement of the ICT as it can ensure shorter response time ${ }^{39}$. The ICT system supports information exchange if different systems are homogeneous, the system combines user-friendly ICT applications and has a high number of users ${ }^{40}$. However, as the European Commission ${ }^{41}$ finds, the large number of non-interoperable databases and communication systems create duplications and hinder cross-border information exchange as it results in delayed responses. Researchers argue that ensuring access authorization, authentication, security, and confidentiality are critical in the design of the ICT system ${ }^{42}$.

\section{RESEARCH METHODOLOGY}

This research aims to answer the question: which factors impede and support the efficiency and speed of cross-border information exchange conducted by the SPOC and PCCC and how the obstacles can be overcome. As the research aims at understanding a case study, the process of cross-border information exchange, and the influencing factors quantitative research was used ${ }^{43}$. Based on the findings of the literature review, a survey study (online questionnaire) was used to collect numerical data about the influencing factors. The items in the questionnaire consisted of a combination of multiple and single choice, 5-point Likert scales, and open-ended questions.

To obtain a satisfactory response to the questionnaire, the author applied convenience sampling ${ }^{44}$. The link to the questionnaire was sent to the functional e-mail addresses of each of the National Frontex Points of Contacts (NFPOC), 28 SPOCs and 64 PCCCs within the EU, from where the questionnaire was sent to all staff and to the end-users and they were asked to disseminate the questionnaire further (snowball sampling). Staff was also asked to forward the questionnaire to the members of its professional network. The researcher published short calls on various professional, social media platforms. They were also distributed by email and instant messages. Hence, the research subjects consisted of the workforce assigned to conduct crossborder exchange in all PCCCs, all SPOCs within the EU and the operational staff of law enforcement agencies. Finally, the sample size (n) consisted of 661 participants. Although not all questions were filled out, the total number of ,n” was generally large enough by estimation to represent the population of the LEAs and to carry out useful analyses. Calculated on 1.653.000

\footnotetext{
${ }^{39}$ J. Zhang, S.S. Dawes, op. cit.; European Commission, Stronger and Smarter Information Systems for Borders and Security, 2016, p.12.

${ }^{40}$ S. Kim, H. Lee, op. cit.

${ }^{41}$ European Commission, Enhancing Police and Customs Cooperation in the European Union, 2004, p.12.

${ }^{42}$ Vide M.Chau et al., Building an Infrastructure for Law Enforcement Information Sharing and Collaboration: Design Issues and Challenges, Proceedings of The National Conference on Digital Government Research 2002.

${ }^{43}$ R.K. Yin, Case Study Research Design and Methods, 2014, p.1.; .A.Bryman, Social Research Methods, 2012, p. 628.

${ }^{44}$ Ibid 202.
} 
police officers within the $\mathrm{EU}^{45}$ and using the commonly accepted $95 \%$ confidence level $^{46}$ and $5 \%$ margin of error, the ideal sample size (n) is $385,{ }^{47}$ which confirms the representative nature of the sample.

IBM SPSS 22.0 software was used to analyse the questionnaire. The author used frequency tables, formulated hypotheses, and conducted correlation tests to find connections between the independent and dependent variables. Finally, a multiple regression analysis was conducted to find the best predictor variables of the efficiency of cross-border information exchange ${ }^{48}$.

\section{RESULTS OF THE QUESTIONNAIRE}

\section{SAMPLE DESCRIPTION AND ANALYSIS}

The demographic variables were split in two categories; general demographic variables (gender, age, and country) and law enforcement-related demographic variables (years in service, experience in cross-border information exchange, role within the service, number of law enforcement services and number of channels used for cross-border information exchange). Three main groups (staff of SPOC, PCCC, and field officers) and one subgroup (commanders) of Law Enforcement Officers from 34 countries completed the online survey between January and February 2019. In total, 661 respondents from across the participating countries completed the questionnaire. Table 1 shows the demographic variables.

\begin{tabular}{llll}
\hline Variables & & $\%$ & $\boldsymbol{N}$ \\
\hline Age & $42.6(\mathrm{SD}=8.44)$ & - & 644 \\
& Male & 81.1 & \\
Gender & Female & 18 & 651 \\
& Prefer not to answer & .9 & \\
& Less than high school & 5.9 & \\
& High school & 19.8 & \\
Education & Bachelor"s degree & 35.8 & 643 \\
& Master"s degree & 33.6 & \\
& Other & 5.0 &
\end{tabular}

\footnotetext{
${ }^{45}$ Eurostat, Eurostat, the Statistical Office of the European Union, Police, Court and Prison Personnel Statistics, 2017.

${ }^{46}$ M. Saunders et al., Research Methods for Business Students , 2008, p.266.

${ }^{47}$ Calculation was made with the help of Qualtrics online program: https://www.qualtrics.com/blog/calculatingsample-size/ (3.03.2019).

${ }^{48}$ Ibid, p. 463.
} 


\begin{tabular}{|c|c|c|c|}
\hline \multirow{5}{*}{ Years in LEA service } & Less than 2 years & 1.6 & \multirow{5}{*}{640} \\
\hline & $3-5$ years & 2.7 & \\
\hline & $6-8$ years & 6.4 & \\
\hline & $9-11$ years & 8.6 & \\
\hline & more than 12 years & 80.8 & \\
\hline \multirow{6}{*}{$\begin{array}{l}\text { Experience in cross-border } \\
\text { information exchange }\end{array}$} & Less than 2 years & 6.8 & \multirow{6}{*}{65} \\
\hline & $3-5$ years & 14.3 & \\
\hline & 6-8 years & 12 & \\
\hline & $9-11$ years & 15.1 & \\
\hline & more than 12 years & 30.9 & \\
\hline & does not apply to me & 20.9 & \\
\hline \multirow{6}{*}{$\begin{array}{l}\text { Role in cross-border } \\
\text { information exchange }\end{array}$} & Staff of SPOC & & \multirow{6}{*}{633} \\
\hline & Staff of PCCC & 10.4 & \\
\hline & Field officer/end-user & 22.1 & \\
\hline & \multirow{2}{*}{ Commander/Supervisor } & 29. & \\
\hline & & 19.1 & \\
\hline & & 18.5 & \\
\hline
\end{tabular}

Table 1. Demographic variables

*Note: Other roles in cross-border information exchange consist of various answers such as criminal analysts, trainers, escort and legal staff, etc.

\section{ORGANISATION STRUCTURE, CENTRALISATION}

Centralisation subscale reflected the centralised nature and supervisory role, which is measured by respondents" views on how centralised their organisation is and whether there is a need for supervisory approval in the decision-making process. Cronbach's alpha was satisfactory (.71). To conduct the correlation analysis, the Organisational Efficiency scale was created from three dependent variables (see Annex 1). The following hypothesis was tested during the correlation analysis:

$H_{0}$ : The degree of centralisation has no impact on the efficiency of the cross-border information exchange.

$H_{1}$ : The degree of centralisation has a (negative) impact on the efficiency of the cross-border information exchange.

In the field of organisational influence, the analysis shows that there is a significant negative correlation between the degree of centralisation and the speed of the cross-border information exchange (within 1 hour) $(\mathrm{r}(334)=-.24, \mathrm{p}<.00$ and $\mathrm{r}(326)=-.15, \mathrm{p}<.01)$ and the 
Organisational Efficiency $(\mathrm{r}(385)=-.16, \mathrm{p}<.01)$. This means that if the level of centralisation is higher, the exchange of information is less efficient. Therefore, the $H_{1}$ hypothesis is accepted.

\section{ORGANISATIONAL SUPPORT}

The next subscale measured the Organisational Support, by questioning the organisational openness to new ideas and the sufficiency of staffing with two items (see Annex 1). The following hypothesis was tested during the correlation analysis:

$H_{0}$ : Organisational support is not related to the efficiency of cross-border information exchange.

$H_{1}$ : Organisational support is positively related to the efficiency of cross-border information exchange.

Analysis shows that there is a significant positive relationship between the degree of Organisational Support and the Speed of cross-border information exchange within 1 hour subscale $(\mathrm{r}(332)=.28 ; \mathrm{p}<.01)$ and the Organisational Efficiency of the cross-border information exchange $(\mathrm{r}(388)=.43, \mathrm{p}<.01)$. More support from the organisation will lead to a faster and more efficient information exchange. Therefore, the $H_{1}$ hypothesis is accepted.

\section{ORgANiSATIONAL CULTURE}

Theoretical review states that common culture supports information exchange, therefore the subscale Organisational Culture of four items reflected the similarity of organisational and personal values, and the culture with counterparts (see Annex 1). The following hypothesis was tested during the correlation analysis:

$H_{0}$ : Culture has no impact on the efficiency of cross-border information exchange and thus satisfaction.

$H_{1}$ : Culture has a positive impact on the efficiency of cross-border information exchange and on satisfaction

The outcome of the questionnaire confirmed the findings of the literature review by substantiating the positive relationship between culture among the counterparts and the efficiency of Organisational cross-border information exchange subscale $(\mathrm{r}(367)=.41, \mathrm{p}<.01)$. Additionally, in relation to other subscales, correlations were found: the speed of information exchange (within 1 hour $(\mathrm{r}(325)=.26, \mathrm{p}<.01)$ and within $1-4$ hours $(\mathrm{r}(316)=.12, \mathrm{p}<.05)$ and the General Efficiency Quality $(\mathrm{r}(363)=.16, \mathrm{p}<.01)$. Therefore, the $H_{1}$ hypothesis is accepted.

\section{LEADERSHIP}

The Leadership and Management subscale was measured with three items representing the conviction that management has an important role in supporting information exchange, including aspects such as the importance of management being a role model (see Annex 1). The internal reliability was satisfactory (Cronbach's alpha $=0.83$ ). The following hypothesis was tested during the correlation analysis:

$H_{0}$ : Leadership is not related to efficient cross-border information exchange. 
$H_{1}$ : Leadership is not related to efficient cross-border information exchange.

Positive significant correlations were found between the Supportive Leadership subscale and the Organisational efficiency subscale $(\mathrm{r}(391)=.57, \mathrm{p}<.01)$ and the speed of cross-border information exchange (within 1 hour $(\mathrm{r}(341)=.21, \mathrm{p}<.01)$ and within $1-4$ hours $(\mathrm{r}(331)=.14$, $\mathrm{p}<.05)$. For this reason, the $H_{1}$ hypothesis is accepted. A supportive leadership climate will lead to a higher efficiency of the organisation and employees will exchange information faster.

\section{REWARDS AND INCENTIVES}

The Incentives subscale with three items was created to measure the impact of performance evaluation and awards on the efficiency of information exchange (see Annex 1). The internal reliability was satisfactory (Cronbach's alpha $=0.72$ ). The following hypothesis was tested during the correlation analysis:

$H_{0}$ : Rewards and incentives are not related to the efficiency of cross-border information exchange.

$H_{1}$ : Rewards and incentives are positively related to the efficiency of cross-border information exchange.

Previously described positive correlations were also demonstrated between the Reward $\&$ Incentives subscale and the Organisational Efficiency subscale $(\mathrm{r}(347)=.21, \mathrm{p}<.01)$ and the overall satisfaction $(\mathrm{r}(301)=.27, \mathrm{p}<.01)$. Additionally, there are correlations between the Reward \& Incentives scale and speed (within one hour $\mathrm{r}(304)=.21, \mathrm{p}<.01$ ) and with speed (within 5-12 hours; $r(292)=.18$ and $p<.01$ ). The more incentives and rewards, the higher the organisational efficiency and speed of the cross-border information exchange. The correlation between rewards and incentives and speed within 5 - 12 hours would probably be biased by the SPOC personnel. Because, for that channel, information exchange within 5 - 12 hours is already considered as a fast exchange of information. Therefore, $H_{1}$ hypothesis is accepted.

\section{FACTORS AND THEIR IMPORTANCE}

The Supporting Factors subscale consisted of 16 items reflecting on the importance of the supporting and hindering factors which were identified during the literature review (see Annex 1). The internal reliability was excellent (Cronbach's alpha $=0.91$ ). The following hypothesis was tested during the correlation analysis.

$H_{0}$ : The supportive factors have no impact on the efficient cross-border information exchange

$H_{1}$ : The supportive factors have a positive impact on the efficient cross-border information exchange.

Analysis shows that the Supportive Factors subscale (trust, reciprocity, good experience, mutual benefit, etc.) positively correlates with General Efficiency Quality $(\mathrm{r}(372)=.27, \mathrm{p}<$ .01 ) and speed (within one hour $\mathrm{r}(309)=.12, \mathrm{p}<.05$ ). This means that the greater the confidence of the employees in the other parties, the more efficiently they experience the information exchange in general and the faster the information exchange proceeds. For this reason, the $H_{1}$ hypothesis is accepted. 


\section{LEGISLATIVE ENVIRONMENT}

The legislative environment section was divided into two subscales, the National Legislation and the EU Legislation subscale. The first subscale embraced eleven items, respondents could choose the correct answers about the presence of hindering and supportive factors within the national legal environment (see Annex 1). The internal reliability was satisfactory (Cronbach's alpha was 0.91 ). The following hypothesis was tested during the correlation analysis:

$H_{0}$ : National legislation has no impact on the efficiency of cross-border information exchange.

$H_{1}$ : National legislation has an impact on the efficiency of cross-border information exchange.

Correlation analysis confirmed the findings of the desk research as significant positive correlations were found between the supportive national legislative environment and the Speed subscale of the information exchange within one hour $(\mathrm{r}(241)=.24, \mathrm{p}<.01)$, and the Organisational Efficiency subscale $(\mathrm{r}(262)=.36, \mathrm{p}<.01)$. This means that if the national legislation creates an appropriate and supportive environment, the efficiency will be higher, and the information exchange will be conducted faster. $H_{1}$ hypothesis is accepted.

The second subscale, the EU Legislation subscale, consisted of four items (see Annex 1). The internal reliability was satisfactory (Cronbach's alpha was in both cases 0.91). The following hypothesis was tested during the correlation analysis:

$H_{0}$ : EU legislation has no impact on the efficiency of cross-border information exchange.

$H_{1}$ : EU legislation has an impact on the efficiency of cross-border information exchange.

A positive significant relationship was also observed between the supportive EU Legislation and organisational efficiency $(\mathrm{r}(325)=.28, \mathrm{p}<.01)$. This means that there is a positive correlation between the supportive EU legislative environment and higher efficiency and Employee satisfaction. $H_{1}$ hypothesis is accepted.

\section{TECHNOLOGICAL ENVIRONMENT}

The next section of the questionnaire consisted of the Technological environment subscale with seven items. The respondents could provide their answers about the situation of the ICT system on the previously described 5-point Likert scale. The items reflected the hindering and supporting factors derived from the theoretical review. The internal reliability was satisfactory (Cronbach's alpha $=0.88$ ). The following hypothesis was tested during the correlation analysis:

$H_{0}$ : ICT has no influence on the efficiency of cross-border information exchange.

$H_{1}$ : ICT has a positive influence on the efficiency of cross-border information exchange.

Supportive ICT environment is actively contributing to the efficiency of cross-border information exchange and the satisfaction we learned from the correlation analysis. The correlation table also shows a positive relationship between the advanced ICT environment and the Organisational efficiency subscale $(\mathrm{r}(330)=.48, \mathrm{p}<.01)$, meaning that with an appropriate and 
supportive ICT environment the organisational efficiency will be higher. Furthermore, a positive significant correlation with the speed of information exchange (within 1 hour) is found $(\mathrm{r}(293)=$ $.21, \mathrm{p}<.01$ ). This means that the experience of a rapid (within one hour) exchange of information will increase with a better ICT supportive climate. $H_{1}$ hypothesis is accepted.

\section{REGRESSION ANALYSIS}

Regression analysis was conducted to test the overall hypothesis. Analysis shows that $14 \%$ of the variance in exchanging information within 1 hour was explained by the demographic variables. After adding all independent variables (hindering and supporting factors), the explained variance increased by another $6 \%(F(12.104)=1.77, p=.06)$, and this was explained exclusively by the PCCC role $(\beta=.26, t=2.13, p=.04)$ which shows that fast information exchange is mostly conducted by the PCCC staff. End-users shall be aware of it, as this channel can be more efficient than the SPOC if a rapid response is needed.

Analyses also show that $11 \%$ of the variance in Efficient Organisational information exchange is explained by the demographic variable, whereas the PCCC role $(\beta=.26, t=2.34$, $p=.02$ ) again plays a crucial role. After adding all correlated independent variables, the explained variance increased to $41 \%(F(12.10)=5.95, p=.00)$, and this was explained exclusively by the Leadership $(\beta=.31, t=2.94, p=.00)$, by the EU Legislation environment $(\beta=.18, t=2.05, p=.04)$. It means that the organisational efficiency is predicted by the leadership climate and the EU legislation environment. This supports the theory which states the importance of these factors in relation to the efficiency.

\section{INDEPENDENT T-TEST, THE EFFICIENCY OF THE SPOC AND PCCC}

We have seen in the regression analyses that the background variables SPOC and PCCC do not predict the efficiency of the organisation. These background valuables neither predict the overall efficiency quality nor the speed of information exchange. We should always take into account all other variables (hindering and supporting) when evaluating the efficiency of the cross-border exchange. However, for a deeper understanding of the efficiency difference between SPOC and PCCC channels and to answer the research subquestion 3, the author conducted a final t-test. This analysis shows that the staff of the SPOCs and the PCCCs are similarly evaluating the complexity of the information exchange, which is conducted by them, however, there is a significant difference in their efficiency. The independent t-test analysis shows that the PCCC is faster, as it conducts information exchange within 1 hour more frequently than the SPOCs $(t=-3.19, \mathrm{p}=.00)$ and information exchange rarely requires more than 12 hours compared to the SPOC $(t=2.52, p=.01)$. PCCC staff consider the supporting factors to be more important than the staff of the SPOC $(\mathrm{t}=-$ $2.25, \mathrm{p}=.03)$. Furthermore, the SPOC has a more centralised structure than the PCCC $(\mathrm{t}=3.0, \mathrm{p}=$ $.00)$. Employee satisfaction on the overall ICT environment $(\mathrm{t}=.15, \mathrm{p}=.88)$, the overall national $(\mathrm{t}=1.3, \mathrm{p}=.20)$ and EU Legislation $(\mathrm{t}=.04, \mathrm{p}=.60)$ are similar on the one hand, on the other hand the staff of PCCCs are more satisfied with the overall and organisational support $(\mathrm{t}=-2.18, \mathrm{p}=.03)$. 


\section{CONCLUSIONS AND RECOMMENDATIONS}

Three main environments have an impact on the efficiency of the exchange of cross-border information, such as the organisational legislation and the ICT environment. The research confirmed the theoretical review, the common and shared organisational culture supports the information exchange process substantially ${ }^{49}$. The highly centralised organisational structure, where leadership favours of strict obedience, lack of openness, lack of staff autonomy, and most decisions require management approval results in a less efficient information exchange process.

Analysis of the questionnaire shows that there is no difference between the quality of the data provided by the SPOC and the PCCC, but significant differences can be found in the speed of the information exchange, as PCCC information exchange is faster than the SPOC. Furthermore, the structure, culture of the organisation and the organisational support relate to organisational efficiency. The supporting factors are predictor variables for the general efficiency quality. Being a member of the PCCC predicts the speed of exchange of information within one hour.

Leadership and EU legislation appeared to be the predictor variables for organisational efficiency. Furthermore, supporting leadership is also important because the competency and knowledge of the leader predicts the efficiency. It supports the findings of T.M. Yang and T.A. Maxwell that emphasise the benefit of the transformational type management model and the use of incentives and feedback. Incentives support the rapid (within 1 hour) information exchange and information exchange within 5-12 hours. For this reason, the management must be aware of the importance of supporting transformational leadership in the efficiency of information exchange, which can be ensured by organizing managerial training courses. Management could introduce a tailor-made incentive system and provide appropriate feedback. This could be supported by the legislation which creates an institutionalised feedback system providing thereby the opportunity to the staff of the channels to be aware of the outcome of their job.

Furthermore, the regression analysis provided the predicting factors. These findings could make us more aware of the importance of supporting factors during information exchange. On this basis, decision makers should take into consideration the importance of various factors, such as mutuality, reciprocity, trust, benevolence, competence, and so on if they intend to increase the efficiency of the information exchange, as it was also stated during the literature review by S. Hufnagel, T.M. Yang and T.A. Maxwell and J. Zhang and S.S. Dawes. Analysis demonstrated that there are important predicting factors for the quality of the efficiency of information exchange, the organisational efficiency, and the speed of the exchange of information. This means that information exchange depends on the importance of the supporting factors, such as mutuality, reputation, trust, and benevolence. The organisational efficiency is predicted by leadership and the EU legislation. Being a PCCC member predicts the speed of information exchange, more precisely, being a PCCC employee predicts that the information exchange will be conducted within 1 hour.

\footnotetext{
${ }^{49}$ D. Constant, op. cit.
} 
The research also enriches the literature by recognising that the current legislation and its various interpretations can decrease the efficiency ${ }^{50}$. Differences in national legislation, various legal systems, and the inappropriate harmonisation and interpretation of the EU regulations also cause complications during everyday work and significantly hinder the efficiency. As the EU legislation seemed to be an important predictor for organisational efficiency, it should also support the timeliness of the information exchange, the deadlines need to be adopted to the everyday needs and therefore should be shortened. Finally, the ICT appeared to be an important predictor next to organisational support. To ensure efficiency, interoperability should be ensured to increase the speed of the channels.

\section{BIBLIOGRAPHY}

Arches Joan. 1991. "Social Structure, Burnout, and Job Satisfaction”. Social Work (36): 202206. https://doi.org/10.1093/sw/36.3.202

Argote Linda, Ingram Paul, Levine John M, Moreland Richard L. 2000. "Knowledge Transfer in Organizations: Learning from the Experience of Others". Organizational Behavior and Human Decision Processes (82): 1-8. https://doi.org/10.1006/obhd.2000.2883

Axelrod Robert and Hamilton Wiliam D. 1981. "The Evolution of Cooperation". Science New Series (211): 1391-1396. http://www-personal.umich.edu/ axe/research/Axelrod and Hamilton EC 1981.pdf

Bock Gee-Woo, Zmud Robert, Kim Young-Gul and Lee Jae-Nam. 2005. "Behavioral Intention Formation in Knowledge Sharing: Examining the Roles of Extrinsic Motivators, SocialPsychological Factors, and Organizational Climate". MIS Quarterly (29): 87-111. https://pdfs.semanticscholar.org/0dc6/e17f67e2a3d2d3288eda958c9eed71257f29.pdf>

Bryman Alan. 2012. Social Research Methods. OXFORD University Press.

Bstieler Ludwig. 2006. "Trust Formation in Collaborative New Product Development”. Journal of Product Innovation Management (23): 56-72. https://doi.org/10.1111/j.15405885.2005.00181.x

Cater Barbara. 2008. "The Importance of Social Bonds for Communication and Trust in Marketing Relationships in Professional Services". Management (13): 1-15. https://hrcak.srce.hr/file/40228

Chau Michael, Zeng Daniel, Atabakhsh Homa and Chen Hsiu-chinu. 2002. "Building an Infrastructure for Law Enforcement Information Sharing and Collaboration: Design Issues and Challenges". Proceedings of The National Conference on Digital Government Research.

Constant David, Kiesler Sara and Sproull Lee. 1994. "What's Mine Is Ours, or Is It? A Study of Attitudes about Information Sharing”. Information Systems Research (5): 400-421. http://www.jstor.org/stable/23010604

Doherty Richard, Vandresse Benoît, Kamarás Éva, Siede Anna, Segerberg Jan, Hert Paul, Mitsilegas Valsamis. 2015. "Study on the Implementation of the European Information Exchange Model (EIXM) for Strengthening Law Enforcement Cooperation”. European

\footnotetext{
${ }^{50}$ J. Zhang, S.S. Dawes, J. Sarkis, op. cit. J.R. Gil-García et al., op. cit.
} 
Commission, Brussels. https://ec.europa.eu/home-affairs/sites/homeaffairs/files/elibrary/documents/policies/police-cooperation/general/docs/eixm_study_-

_final_report_en.pdf

European Commission. 2004. Enhancing Police and Customs Cooperation in the European Union [COM (2004) 376 Final - Not Published in the Official Journal]. http://eurlex.europa.eu/legal-content/EN/TXT/HTML/?uri=LEGISSUM:116000\&from=EN

European Commission. 2015. A European Agenda on Migration $\operatorname{COM(2015)~} 240$ Final. http://www.europarl.europa.eu/oeil/popups/ficheprocedure.do?lang=en\&reference=201 $5 / 2660$

European Commission. 2016. Stronger and Smarter Information Systems for Borders and Security, $\operatorname{COM}(2016) 205$ Final. https://ec.europa.eu/home-affairs/sites/homeaffairs/ files/e-library/documents/policies/policecooperation/general/docs/20121207_com_2012_735_en.pdf

European Police Office. 2017. "Serious and Organised Crime Threat Assessment". Europol, The Hague.

European Union. 1985. The Schengen Acquis - Convention Implementing the Schengen Agreement of 14 June 1985 between the Governments of the States of the Benelux Economic Union, the Federal Republic of Germany and the French Republic on the Gradual Abolition of Checks at Their C (1985). https://eur-lex.europa.eu/LexUriServ/ LexUriServ.do?uri=CELEX\%3A42000A0922\%2802\%29\%3AEN\%3AHTML

Eurostat. 2017. Eurostat, the Statistical Office of the European Union, Police, Court and Prison

Personnel Statistics. https://ec.europa.eu/eurostat/statistics-explained/index.php?title =Police,_court_and_prison_personnel_statistics\&stable=0\&redirect=no\#One_police_of ficer_per_309_people

Frontex. 2017. Roles \& Responsibilities. https://frontex.europa.eu/operations/rolesresponsibilities/

Gabor Kemeny. 2020. "A qualitative analysis of the hindering and supporting factors of the cross-border information exchange conducted by the single point of contact and the police and customs cooperation centre". Public Security and Public Order (24): 101-126. https://repository.mruni.eu/handle/007/16559

Gil-García J. Ramon, Schneider Carrie A, Pardo Theresa A, Cresswell Anthony M. 2005. "EGovernment Success Factors: Mapping Practical Tools to Theoretical Foundations". $\begin{array}{llll}\text { Government } & \text { Information } & \text { Quarterly } & \text { (22): }\end{array}$ http://www.sciencedirect.com/science/article/pii/S0740624X05000158

Goldenberg Irina and Dean Waylon H. 2017. Enablers and Barriers to Information Sharing in Military and Security Operations: Lessons Learned in Information sharing in military operations. Springer Cham.

Hufnagel Saskia. 2016. Policing Cooperation across Borders. London: Routledge.

Kim Soonhee and Lee Hyangsoo. 2006. "The Impact of Organizational Context and Information Technology on Employee Knowledge-Sharing Capabilities". Public Administration Review (66): 370-385. https://doi.org/10.1111/j.1540-6210.2006.00595.x

Koeszegi Sabine T. 2004. "Trust-building Strategies in Inter-organizational Negotiations". Journal of Managerial Psychology (19): 640-660. https://doi.org/10.1108/026839 40410551534 
Lane Christel and Bachmann Reinhard. 1996. "The Social Constitution of Trust: Supplier Relations in Britain and Germany". Organization Studies (17): 365-395. https://doi.org/10.1177/017084069601700302

Lunenburg Fred C. 2012. “Organizational Structure: Mintzberg's Framework”. International Journal of Scholary (14.):1-8.

Mausolf Adam. 2010. Keeping Up Appearances: Collaboration and Coordination in the Fight against Organized Crime and Terrorism. University of Leiden.

Mintzberg Henri. 1989. The Structuring of Organizations in Readings in Strategic Management. London: Palgrave. https://link.springer.com/chapter/10.1007/978-1-34920317-8_23

Rainey Hal G. 1992. Understanding and Managing Public Organizations. Jossey-Bass, San Francisco. https://doi.org/10.1002/pam.4050110432

Resteigne Delphine and Bogaert Steven Van den. 2017. Information Sharing in Contemporary Operations: The Strength of SOF Ties in, Information Sharing in Military Operations. Springer, Cham. https://link.springer.com/chapter/10.1007\%2F978-3-319-42819-2_4

Rousseau Denise M. 1978. "Characteristics of Departments, Positions, and Individuals: Contexts for Attitudes and Behavior”. Administrative Science Quarterly (23): 521-540. www.jstor.org/stable/2392578

Saloven Matjaz, Grant Euan, Hanel Peter, Makai Viktor, Brent Hansen K., Belevicius Linas and Pohnitzer Angelika. 2010. Study on the Status of Information Exchange amongst Law Enforcement Authorities in the Context of Existing EU Instruments. European Commission, Brussels. https://ec.europa.eu/homeaffairs/sites/homeaffairs/files/doc_centre/police/docs/icmpd_study_lea_infoex.pdf

Saunders Mark, Lewis Philip and Thornhill Adrian. 2008. Research Methods for Business Students. London: Pearson Education Limited.

Soeters Joseph. 2017. Information Sharing in Military and Security Operations in Information Sharing in Military Operations. Cham: Springer.

Styczyńska Izabella, Beaumont Eszter-Zolyomi. 2017. Easing Legal and Administrative Obstacles in EU Border Regions. European Commission, Brussels. http://ec.europa.eu/regional_policy/sources/docgener/studies/pdf/obstacle_border/final_ report.pdf

Sydow Jörg. 1998. rust within and between Organizations in Understanding the constitution of inter-organizational trust. Oxford University Press.

Travica Bob. 1998. "Information Aspects of New Organizational Designs: Exploring the NonTraditional Organization". Journal of the American Society for Information Science (49): 1224-1244.

Weibel Dimitri. 2016. Police and Border Cooperation in Schengen: The Police and Customs Cooperation Center (PCCC). Leiden University. https://openaccess.leidenuniv.nl/bitstream/handle/1887/40745/Weibel\%2CDimitris1711172-MA Thesis-2016.pdf?sequence=1

Wheatley Margaret J. 2006. Leadership and the New Science: Discovering Order in a Chaotic World. San Francisco: Berrett-Koehler Publishers.

Willem Annick and Buelens Marc. 2007. "Knowledge Sharing in Public Sector Organizations: The Effect of Organizational Characteristics on Interdepartmental Knowledge Sharing”. 
Journal of Public Administration Research and Theory (17): 581-606.

Yang Tung-Mou and Maxwell Terrence A. 2011. "Information-Sharing in Public Organizations: A Literature Review of Interpersonal, Intra-Organizational and InterOrganizational Success Factors". Government Information Quarterly (28): 164-175.

Yin Robert K. 2014. Case Study Research Design and Methods. Thousand Oaks, CA: Sage.

Zhang Jing and Dawes Sharon S. 2006. "Expectations and Perceptions of Benefits, Barriers, and Success in Public Sector Knowledge Networks". Public Performance \& Management Review (29): 433-466. www.jstor.org/stable/20447606

Zhang J, Dawes Sharon S and Sarkis Joseph. 2005. "Exploring Stakeholders' Expectations of the Benefits and Barriers of E-government Knowledge Sharing". Journal of Enterprise Information Management (18): 548-567. https://doi.org/10.1108/17410390510624007

Annex 1. Questionnaire and subscales

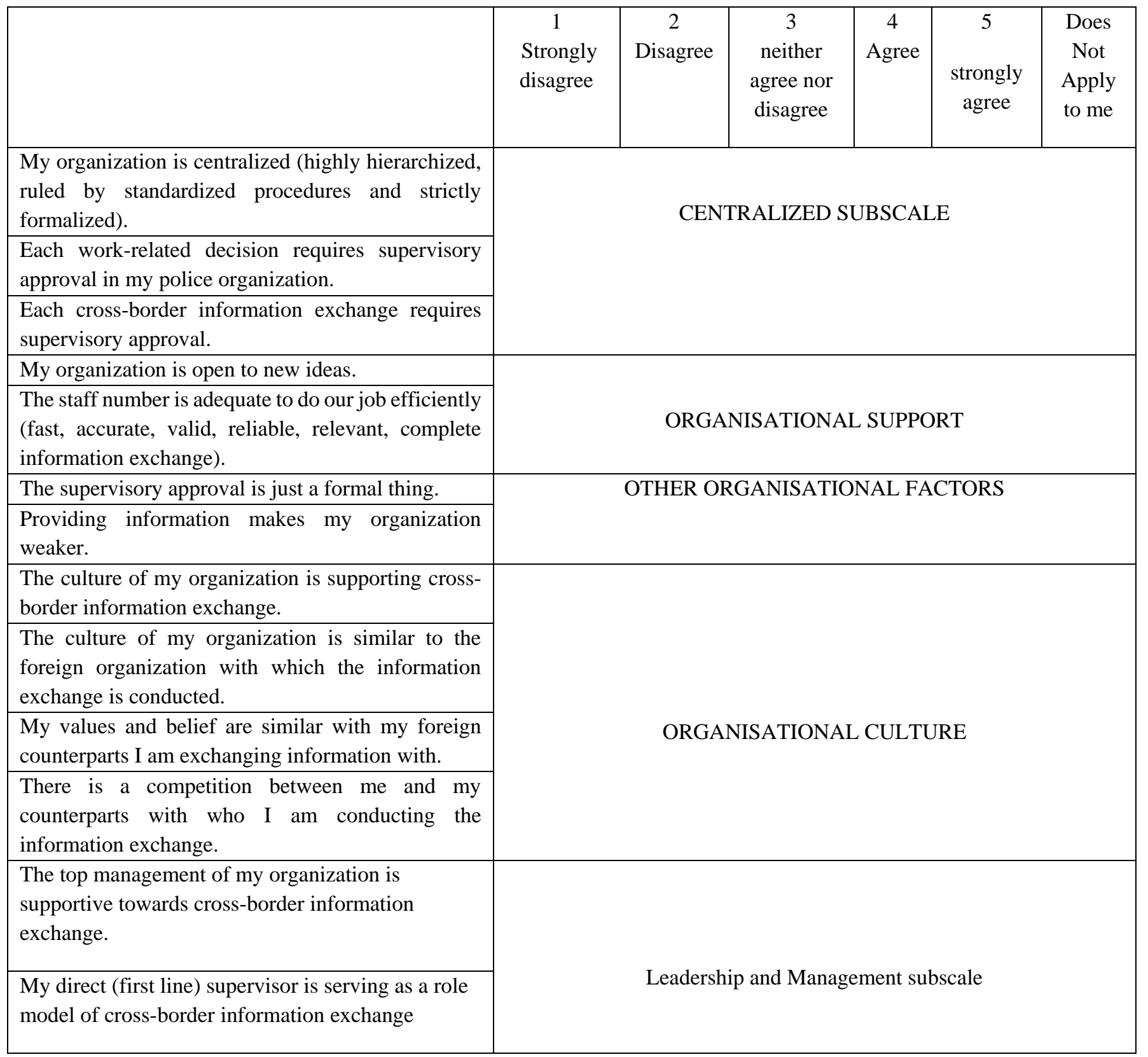




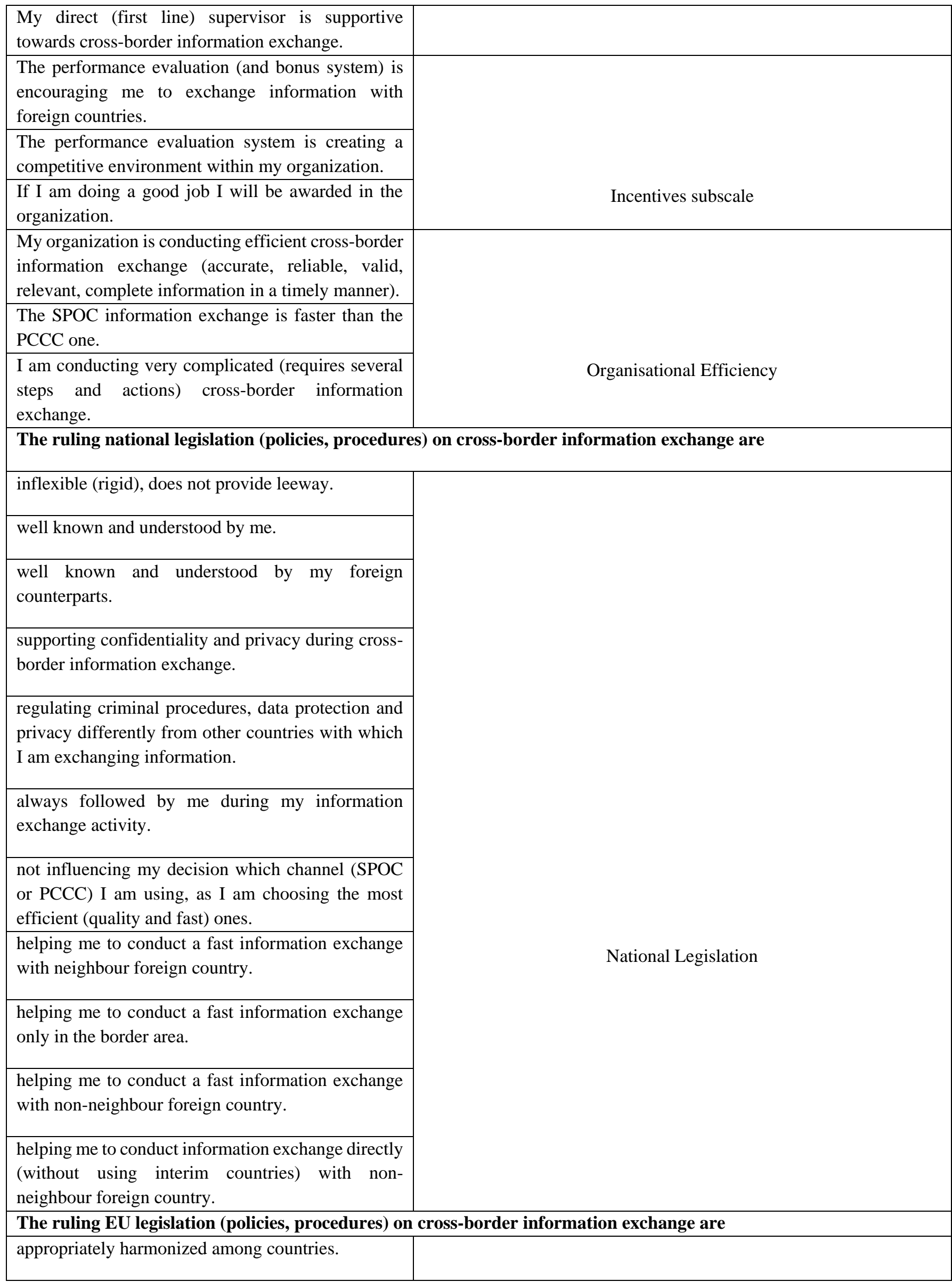




\begin{tabular}{|c|c|}
\hline \multicolumn{2}{|l|}{ similarly interpreted by each country. } \\
\hline $\begin{array}{l}\text { similarly interpreted by individuals (interpretation is } \\
\text { not depending on the person). }\end{array}$ & \multirow{2}{*}{ EU Legislation subscale } \\
\hline $\begin{array}{l}\text { helping me to conduct fast cross-border information } \\
\text { exchange. }\end{array}$ & \\
\hline \multicolumn{2}{|l|}{ I believe the ICT environment of my organization is } \\
\hline advanced and modern (state of art). & \multirow{7}{*}{ Technological environment subscale } \\
\hline user friendly and easy to use. & \\
\hline widely used by the staff. & \\
\hline supporting a fast cross-border information exchange. & \\
\hline $\begin{array}{l}\text { interoperable and compatible with the ICT system of } \\
\text { my counterparts. }\end{array}$ & \\
\hline $\begin{array}{l}\text { ensuring the availability of all databases which are } \\
\text { required to conduct cross-border information } \\
\text { exchange. }\end{array}$ & \\
\hline $\begin{array}{l}\text { ensuring adequate privacy and security (secured } \\
\text { network, channel) to conduct cross-border } \\
\text { information exchange. }\end{array}$ & \\
\hline
\end{tabular}

\section{Efficient cross-border information exchange is when the shared information is}

\begin{tabular}{|c|c|c|c|c|c|c|c|c|c|c|c|}
\hline & 1 & 2 & 3 & 4 & 5 & 6 & 7 & 8 & 9 & 10 & $\begin{array}{c}\text { Does } \\
\text { Not } \\
\text { Apply } \\
\text { to me }\end{array}$ \\
\hline accurate. & \\
\hline reliable. & & & & & & & & & & & \\
\hline valid. & & & & & & & & & & & \\
\hline \multirow{3}{*}{$\begin{array}{l}\text { relevant. } \\
\text { complete. } \\
\text { quick. } \\
\end{array}$} & & & & & & & & & & & \\
\hline & & & & & & & & & & & \\
\hline & & & & & & & & & & & \\
\hline \multicolumn{12}{|l|}{ How important is the } \\
\hline & \multicolumn{2}{|c|}{$\begin{array}{l}\text { Not at all } \\
\text { important }\end{array}$} & \multicolumn{2}{|c|}{$\begin{array}{l}\text { Slightly } \\
\text { important }\end{array}$} & \multicolumn{2}{|c|}{ Important } & \multicolumn{2}{|c|}{$\begin{array}{c}\text { Fairly } \\
\text { important }\end{array}$} & \multicolumn{2}{|c|}{$\begin{array}{c}\text { Very } \\
\text { important }\end{array}$} & $\begin{array}{l}\text { Does } \\
\text { Not } \\
\text { Apply } \\
\text { to me }\end{array}$ \\
\hline \multicolumn{12}{|l|}{ mutual interest. } \\
\hline \multicolumn{12}{|l|}{ common and shared goals. } \\
\hline \multicolumn{12}{|l|}{ privacy and confidentiality. } \\
\hline \multicolumn{12}{|l|}{ mutual benefit. } \\
\hline \multicolumn{12}{|l|}{ reciprocity. } \\
\hline organizational reputation. & & & & & & & & & & & \\
\hline
\end{tabular}


personal reputation.

integrity of the counterpart.

competence (knowledge) of the counterpart.

benevolence (good will) of the counterpart.

trust towards the foreign organization.

trust between the groups (e.g. managers) of different organizations.

trust towards my counterparts with who I am exchanging information.

use of common language.

team-building activities between the staff of my and the foreign organization.

Supporting Factors subscale

information-exchange specific training activities. 